\title{
Faktor-faktor yang Berhubungan dengan Pemberian Imunisasi Campak pada Balita
}

\author{
Sevilla Ukhtil Huvaid ${ }^{\mathrm{a}}$, Yulianita ${ }^{\mathrm{b} *}$, Nola Mairoza \\ Fakultas Kesehatan Masyarakat, Universitas Baiturrahmah, Padang 25586, Indonesia \\ asevilla.kesmas@gmail.com, byuliazallia@gmail.com* \\ * corresponding author
}

ARTICLE INFO

Keywords

Measles Immunization

Toddler

Knowledge

Attitude

Role of Cadres

\begin{abstract}
Measles immunization is complete basic immunization that must be given to children from 9 to 59 months. Measles immunization coverage in the Limau-Limau Posyandu at the Asam Kumbang Health Center has decreased from $69.2 \%$ to $41.9 \%$. The purpose of this study was to determine the relationship between knowledge, attitudes, and roles of cadres and measles immunization in infants. This study uses a cross sectional approach. The population in this study were all mothers with children (9-59 months). The sample is all toddlers, while the respondents are all mothers who have toddlers with a total sampling technique. Analysis was performed using Chi Square test. The univariate results in this study indicate that more respondents did not bring their children for measles immunization (59.5\%) more than half of respondents had low knowledge $(64.9 \%)$, more than half of respondents were negative $(62.2 \%)$, and more of half of respondents said the cadre's role was not good $(62.2 \%)$ for measles immunization in infants. Bivariate results showed that there was a significant relationship between knowledge, attitudes and roles of cadres and measles immunization for infants $(\mathrm{p}=0,000)$. For this reason, it is necessary to increase the frequency of counseling and training of cadres in order to change the role of cadres from less good to better, in addition respondents respondents must increase active participation in extension activities in order to increase knowledge.
\end{abstract}

\section{Pendahuluan}

Program imunisasi lengkap mencakup BCG, Hepatitis B, DPT-HB, Polio, dan Campak.Termasuk penyakit yang dapat dicegah dengan melakukan imunisasi, atau biasa disebut dengan PD3I (Penyakit yang Dapat Dicegah dengan Imunisasi), penyakit - penyakit tersebut adalah Tuberculosis, Hepatitis B, Difteri, Pertusis, Tetanus, Campak, dan Polio [1].

Imunisasi menjadi penting karena dapat melindungi dari berbagai penyakit yang berbahaya. Penyakit yang Dapat Dicegah Dengan Imunisasi (PD3I) masih menyita perhatian yang salah satunya adalah Penyakit Campak.Penyakit Campak dikenal dengan nama morbili, merupakan penyakit yang sangat menular (infeksius) yang disebabkan oleh virus golongan paramyxoviridae (RNA), 90\% anak yang tidak kebal akan terserang Penyakit Campak. Manusia diperkirakan satu-satunya reservoir, walaupun monyet dapat terinfeksi tetapi tidak berperan dalam penyebaran. Penularan terjadi melalui batuk, bersin (sekret hidung). Penularan dapat terjadi 1-3 hari sebelum panas[2]. 
Pada tahun 2010 WHO bersama UNICEF (United Nations Children'sFund) membuat rencana strategi global maupun regional 2010-2015 yang memiliki tujuan program pengendalian penyakit campak dengan mengurangi angka kematian Campak sebesar 90\% (estimated) pada tahun 2015. Menurut regional and global summaries of Morbili incidence, angka insidens campak di wilayah South-East Asia (SEARO) adalah 75.770. Indonesia termasuk salah satu dari 47 negara penyumbang kasus Campak terbesar di dunia. Prevalensi campak tertinggi pada anak balita $(3,4 \%)$ dan masih cukup tinggi ditemukan pada usia di bawah 5 tahun. Kematian anak akibat Penyakit yang dapat dicegah dengan Imunisasi (PD3I) di Indonesia adalah 1,7 juta kematian dan 5\% penyebab kematian anak di bawah lima tahun (3,4\%) [3].

Berdasarkan Riset Kesehatan Dasar Indonesia tahun 2013 cakupan imunisasi Campak pada anak umur 12-23 bulan (85,9\%) sedangkan menurut Kemenkes 2014 (71,4\%), jadi dapat disimpulkan antara tahun 2013 ke tahun 2014 cakupan capaian imunisasi campak menurun, disamping itu pada tahun 2014 Sebanyak 25 provinsi mempunyai cakupan capaian imunisasi Campak di bawah standar nasional salah satunya Provinsi Sumatera Barat, Selain itu berdasarkan Incidence Rate (IR) Campak di Indonesia, Provinsi Sumatera Barat termasuk ke dalam 10 provinsi dengan angka insidens kejadian campak yang tinggi yaitu 9,99 per 100.000 penduduk [4].

Data dari Dinas Kesehatan Provinsi Sumatera Barat, pada tahun 2015 capaian imunisasi campak masih rendah diberbagai kabupaten dan kota yang ada di Sumatera Barat salah satunya Kabupaten Pesisir Selatan. Selama 5 tahun berturut-turut pencapaian cakupan imuniasi campak pada balita di Kabupaten Pesisir selatan berada di bawah Standar Pelayanan Minimal (SPM) yaitu 90\%. Pada tahun 2011 yaitu 79\%, tahun 2012 yaitu 88\%, tahun 2013 yaitu $71,3 \%$, tahun 2014 yaitu 48,4\% Selain itu berdasarkan pencapaian imunisasi campak terendah pada tahun 2015 dari 18 Puskesmas di Kabupaten Pesisir Selatan, Puskesmas asam kumbang termasuk puskesmas yang memiliki cakupan yang rendah yaitu 69,2\% [5].

Berdasarkan survei pendahuluan yang dilakukan pada tanggal 10 Januari 2016 kepada 10 Ibu yang mempunyai Balita diketahui bahwa 6 orang dari $10 \mathrm{Ibu}$ Balita $(60 \%)$ tidak membawa anak imunisasi campak, 5 orang (50\%) tidak mengetahui apa tujuan pemberian imunisasi campak, 5 orang (50\%) mempunyai persepsi bahwa setelah diberikan imunisasi campak balita akan mengalami demam serta timbul bintik-bintik merah di badan, 7 orang $(70 \%)$ tidak mendapatkan dukungan kader dan 3 orang (30\%) menyatakan tidak tersedianya fasilitas untuk pemberian Imunisasi Campak.Dari latar belakang inilah maka peneliti tertarik untuk mengetahui lebih jauh tentang faktor-faktor yang berhubungan dengan pemberian imunisasi campak pada balita Posyandu Limau-limau wilayah kerja Puskesmas Asam Kumbang Kabupaten Pesisir Selatan.

\section{Metode}

Jenis penelitian ini adalah merupakan penelitian kuantitatif dengan pendekatan cross sectionalstudy dimana variabel dependen (pemberian imunisasi campak), dan variabel independen (Pengetahuan, Sikap, dan Peran Kader ) dikumpulkan pada waktu bersamaan.

Penelitian dilakukan di Posyandu Limau-Limau Wilayah Kerja Puskesmas Asam Kumbang Kabupaten Pesisir Selatan.Populasi penelitian ini adalah seluruh ibu yang mempunyai balita yang berumur 9-59 bulan yang terdata di Posyandu Limau-Limau Kenagarian Limau Gadang yang berjumlah 37 orang. Sampel dalam penelitian ini ditentukan dengan total sampling dimana seluruh populasi dijadikan sampel.

Uji yang digunakan untuk menganalisa data adalah uji Chi-Square dilakukan dengan tujuan untuk mengetahui kemaknaan hubungan variabel independen dan dependen, hubungan kedua variabel dikatakan bermakna jika P Value< 0,05 dengan derajat kepercayaan 95\%.

\section{Hasil dan Diskusi}

Analisis Univariat

a. Pemberian Imunisasi Campak

Berikut dapat dilihat tabel distribusi responden berdasarkan pemberian imunisasi campak. 
Tabel 1. Distribusi Responden Berdasarkan Pemberian Imunisasi Campak

\begin{tabular}{|c|c|c|c|}
\hline No. & Pemberian Imnuisasi Campak & $\mathbf{f}$ & $\%$ \\
\hline 1. & Tidak di berikan & 22 & 59,5 \\
\hline 2. & Diberikan & 15 & 40,5 \\
\hline & Total & 37 & 100 \\
\hline
\end{tabular}

Berdasarkan tabel 1 dapat diketahui bahwa lebih dari separuh (59,5\%) responden tidak membawa balitauntuk imunisasi campak ke posyandu di Posyandu Limau-limauWilayah Kerja Puskesmas Asam Kumbang.

Menurut Kemenkes dalam penelitian Nurni (2012) Penyakit campak merupakan salah satu penyakit PD3I(Penyakit yang Dapat Dicegah Dengan Imunisasi) [6]. Imunisasi campak merupakan salah satu jenis imunisasi untuk mencegah penyakit campak dan merupakan salah satu imunisasi dasar dari program dasar yang dicanangkan oleh pemerintah, jadi masyarakat bisa melakuakn imuisasi campak di puskesmas, rumah sakit, dan posyandu.

\section{b. Tingkat Pengetahuan Responden}

Berikut dapat dilihat tabel distribusi responden berdasarkan tingkat pengeta-huan.

Tabel 2. Distribusi Tingkat Pengetahuan

\begin{tabular}{clccc}
\hline \multirow{2}{*}{ No. } & \multicolumn{2}{c}{ Tingkat Pengetahuan Responden } & f & \% \\
\hline 1. & Rendah & & 24 & 64,9 \\
2. & Tinggi & \multirow{2}{*}{ Total } & 13 & 35,1 \\
& & & 37 & $\mathbf{1 0 0}$ \\
\hline
\end{tabular}

Berdasarkan tabel 2. di atas dapat diketahui bahwa lebih dari separuh $(64,9 \%)$ responden dengan tingkat pengetahuan rendah mengenai imunisasi campak terhadap balita.

Pengetahuan ibu tentang imunisasi sangat diperlukan karena dengan pengetahuan yang tinggi tentang imunisasi diharapkan ibu mengimunisasi anaknya secara lengkap. Imunisasi sangat diperlukan oleh seorang anak,dengan imunsasi secara lengkap maka anak akan mempunyai kekebalan tubuh yang kuat dan tidak mudah terserang penyakit [7].

\section{c. Sikap Responden}

Berikut dapat dilihat tabel distribusi responden berdasarkan sikap.

Tabel 3. Distribusi Sikap Responden

\begin{tabular}{cccc}
\hline No. & Sikap Responden & f & \% \\
\hline 1. & Positif & 14 & 37,8 \\
2. & Negatif & 23 & 62,2 \\
& Total & $\mathbf{3 7}$ & $\mathbf{1 0 0}$ \\
\hline
\end{tabular}

Berdasarkan tabel 3. dapat diketahui bahwa lebih dari separuh $(62,2 \%)$ responden bersikap negatif mengenai pemberian imunisasi campak pada Balita.

Salah satu aspek yang sangat penting guna memahami sikap dan perilaku manusia adalah pengungkapan (assesment) atau pengukuran (measurement) sikap. Sikap merupakan respons evaluatif yang dapat berbentuk positif maupun negatif [8]. Sikap mempunyai arah, artinya sikap terpilah pada dua arah kesetujuan yaitu apakah setuju atau tidak setuju, apakah mendukung atau tidak mendukung, apakah memihak atau tidak memihak terhadap sesuatu. Orang yang setuju, mendukung atau memihak terhadap suatu objek berarti memiliki sikap yang arahnya positif sebaliknya mereka yang tidak setuju atau tidak mendukung dikatakan memiliki sikap negatif[9]. 
d. Peran Kader

Berikut dapat dilihat tabel distribusi jawaban responden berdasarkan peran kader.

Tabel 4. Distribusi Peran Kader terhadap Pemberian Imunisasi Campak

\begin{tabular}{|c|c|c|c|}
\hline No. & Peran Kader terhadap Imunisasi Campak pada Balita & $\mathbf{f}$ & Persentase $(\%)$ \\
\hline 1. & Baik & 14 & 37,8 \\
\hline 2. & Kurang baik & 23 & 62,2 \\
\hline & Total & 37 & 100 \\
\hline
\end{tabular}

Berdasarkan tabel 4. dapat diketahui bahwa menurut responden $62,2 \%$ peran kader kurang baik terhadap pemberian imunisasi campak pada balita.Kader Posyandu bertanggung jawab penuh terhadap masyarakat setempat serta pimpinan yang ditunjuk oleh pusat pelayanan kesehatan. Diharapkan mereka melaksanakan petunjuk yang diberikan oleh para pembimbing dalam jalinan kerja sama dari sebuah tim kesehatan.

\section{Analisis Bivariat}

\section{a. Hubungan Tingkat Pengetahuan dengan Pemberian Imunisasi Campak pada Balita}

Hasil penelitian menunjukkan bahwa dari seluruh responden yang berpengetahuan rendah hanya $(8,3 \%)$ yang memberikan imunisasi campak terhadap balitanya. Sedangkan seluruh responden yang berpengetahuan tinggi seluruhnya (100\%) memberikan imunisasi campak terhadap balitanya. Setelah dilakukan uji statistik, diperoleh hasil $p$ value $=0,000(p<\alpha)$, ini berarti ada hubungan antara pengetahuan responden dengan pemberian imunisasi campak pada balita.

Hasil penelitian ini sejalan dengan penelitian yang dilakukan oleh Nur Jannah (2012) di Puskesmas Mangarabombang Kabupaten Takalar. Ditemukan adanya hubungan pengetahuan terhadap pemberian imunsasi campak pada balita dengan nilai $p=0,004$ [10].

Keinginan ibu untuk mengimunisasi anaknya erat kaitanya dengan kesdaran ibu untuk kesehatan anaknya. Dari hasil penelitian menunujukkan bahwa terdapat hubungan yang bermakna antara tingkat pengetahuan ibu dengan pemberian imunisasi campak. Dengan pengetahuan yang dimiliki oleh ibu akan mempengaruhi sikap ibu untuk mengimunisasi anaknya atau tidak. Hal ini sesuai dengan pendapat yang menyatakan bahwa salah satu faktor predisposisi, salah satunya adalah pengetahuan ibu [7].

Pengetahuan merupakan domain yang sangat penting dalam membentuk tindakan seseorang (overt behaviour) [11].Pengetahuan ibu tentang imunisasi campak perlu ditingkatkan, sehingga dapat memberikan pengaruh yang positif untuk kesehatan anak baik masa sekarang maupun untuk masa yang akan datang.

\section{b. Hubungan Sikap Responden dengan Pemberian Imunisasi Campak}

Hasil penelitian menunjukkan bahwa dari seluruh responden responden yang bersikap negatif hanya $(4,3 \%)$ yang memberikan imunisasi campak terhadap balitanya. Sedangkan dari seluruh responden yang bersikap negatif seluruhnya (100\%) memberikan imunisasi campak terhadap balitanya. responden. Setelah dilakukan uji statistik, diperoleh hasil $p$ value $=0,000(p<\alpha)$, ini berarti ada hubungan antara Sikap responden dengan pemberian imunisasi campak pada balita.

Hasil penelitian ini sejalan dengan penelitian yang dilakukan oleh oleh Nur Jannah (2012) di Puskesmas Mangarabombang Kabupaten Takalar, yang menyatakan adanya hubungan sikap ibu dengan penerapan imunisasi campak, dengan nilai $p=0,002[10]$. Hasil penelitian ini sesuai dengan teori yang menyatakan adanya hubungan anatara sikap, kepercayaan dan dan tingkat pengetahuan dengan pemberian imunisasi campak [7].

Sikap merupakan penentu dalam tingkah laku. Sikap yang ada pada seseorang akan pemberikan gambaran bagaiman tanggapan dan tindakan yang akan dilakukan, jika reponden besikap positif akan memberikan gambaran bahwa responden akan cenderung membawa anaknya untuk di berikan imunisasi campak begitu pula sebaliknya, jika responden bersikap negatif maka juga akan 
memberikan gambaran bahwa responden akan cenderung tidak akan membawa anaknya imunisasi campak.

\section{c. Hubungan Peran Kader dengan Pemberian Imunisasi Campak}

Berdasarkan hasil analisis, dari seluruh responden yang mengatakan peran kader kurang baik hanya $(4,3 \%)$ yang memberikan imunisasi campak terhadap balitanya. Sedangkan dari seluruh responden yang mengatakan peran kader tergolong baik sekuruhnya (100\%) memberikan imunisasi campak terhadap balitanya. Setelah dilakukan uji statistik, diperoleh hasil $p$ value $=0,001(p<\alpha)$, ini berarti ada hubungan yang signifikan antara peran kader dengan pemberian imunisasi campak pada balita.

Penelitian ini sejalan dengan penelitian yang dilakuakn oleh Erni Hartati (2012) yang menyatakan adanya hubungan antara peran kader dengan pemberian imnuisasi campak pada balita dengan nilai $p=0,003[12]$.

\section{Pembahasan}

Tenaga kesehatan memegang peranan penting dalam memberikan informasi tentang imunisasi sesuai dengan jadwal pemberian imunisasi. Di samping itu, pentingnya adanya kader posyandu, kader posyandu adalah seseorang yang berasal dari masyarakat setempat dan dipilih oleh masyarakat, dimana mau dan mampu dilatih dan bekerja secara sukarela dalam melakukan penyuluhan dan menggerakkan masyarakat serta mengelola dan meningkatkan kegiatan posyandu dalam rangka meningkatkan status imunisasi dan kesehatan masyarakat.

Peran kader dalam pelaksanaan imunisasi campak sangat diperlukan, jika peran kader baik menurut responden maka responden akan lebih semangat untuk membawa anaknya ke Posyandu untuk imunisasi khususnya imunisasi campak. Dengan demikian kader harus memberikan informasi, motivasi, himbauan dan penyuluhan kepada responden supaya responden lebih giat lagi untuk membawa anaknya imunisasi campak, biasanya keaktifan kader adalah semangat responden.

\section{Kesimpulan}

Hasil analisis univariat dalam penelitian ini menunjukkan bahwa lebih banyak responden tidak membawa anaknya untuk imunisasi campak $(59,5 \%)$ lebih dari setengah responden memiliki pengetahuan rendah $(64,9 \%)$, lebih dari setengah responden negatif $(62,2 \%)$, dan lebih dari setengah dari responden mengatakan peran kader kurang baik $(62,2 \%)$ untuk imunisasi campak pada balita. Hasil bivariat menunjukkan ada hubungan yang signifikan antara pengetahuan, sikap dan peran kader dengan pemberian imunisasi campak pada balita $(\mathrm{p}=0,000)$.

Untuk itu perlu adanya meningkatkan frekuensi penyuluhan dan pelatihan kader guna merubah peran kader dari yang kurang baik menjadi lebih baik, di samping itu responden responden harus meningkatkan partisipasi aktif dalam kegiatan penyuluhan guna meningkatkan pengetahuan.

\section{Referensi}

[1] Dinengsih, S., \& Hendriyani, H. (2018). Hubungan Antara Pendidikan, Pengetahuan, Dukungan Keluarga dan Peran Tenaga Kesehatan dengan Kepatuhan Ibu dalam Melakukan Imunisasi Dasar pada Bayi Usia 0-12 Bulan Di Desa Aweh Kabupaten Lebak Provinsi Banten. Jurnal Kesehatan Kusuma Husada, 202-212.

[2] Juliani, A., Sidik A, D., \& Rismayanti. (2012). Evaluasi Program Imunisasi Puskesmas di Kota Makassar tahun 2012.

[3] Kemenkes. Status Campak dan Rubella saat ini di Indonesia. , (2018).

[4] Pusdatin. (2016). Situasi Imunisasi di Indonesia.

[5] Kesehatan, D., \& Kabupaten Pesisir Selatan. (2017). Laporan Kinerja (LKJ) Dinas Kesehatan Kabupaten Pesisir Selatan Tahun 2017.

[6] Andriani, L. (2017). Hubungan Karakteristik Balita, Umur Saat Imunisasi Campak, Riwayat ASI Eksklusif terhadap Campak Klinis. Jurnal Berkala Epidemiologi, 5(June), 265-272. 
https://doi.org/10.20473/jbe.v5i2.2017.265-275

[7] Isyani Rahmawati, A., \& Umbul W, C. (2014). Faktor yang Mempengaruhi Kelengkapan Imunisasi Dasar di Kelurahan Krembangan Utara. Jurnal Berkala Epidemiologi, 2(Januari), 59-70.

[8] Suharto, \& Suminar, R. (2016). Hubungan Pengetahuan dan Sikap Perawat Dengan Tindakan Pencegahan Infeksi di Ruang ICU Rumah Sakit. Jurnal Riset Hesti Medan, 1(1), 1-10.

[9] Widyani Palupi, A. (2011). Pengaruh Penyuluhan Imunisasi terhadap Peningkatan Pengetahuan dan Sikap Ibu tentang Imunisasi Dasar Lengkap pada Bayi Sebelum Usia 1 Tahun. Retrieved from https://eprints.uns.ac.id/id/eprint/6114.

[10] Jannah, N., Abdullah, A. Z., \& Leida M. Thaha, I. (2013). Faktor yang Berhubungan dengan Status Imunisasi Campak pada Batita di Wilayah Kerja Puskesmas Mangarabombang Kabupaten Takalar. 1-10.

[11] Lubis, R. C. (2016). Tingkat Pengetahuan Ibu Nifas tentang Metode Amenore Laktasi (Mal) Di Klinik Bersalin Aisyah Medan Tahun 2016. Jurnal Riset Hesti Medan, 1(2), 140-145.

[12] Suharti, E. (2012). Hubungan Faktor Pengetahuan, Sikap, dan Dukungan Keluarga dengan Perilaku Kunjugan ke Posyandu pada Ibu Pekerja di Banjarnegara Jawa Tengah. https://doi.org/10.1017/CBO9781107415324.004 